\title{
Article \\ Study on the Ozone Gas Sensing Properties of rf-Sputtered Al-Doped NiO Films
}

\author{
Athanasios Paralikis ${ }^{1,2}$, Emmaouil Gagaoudakis ${ }^{1, *}$, Viktoras Kampitakis ${ }^{1,2}$, Elias Aperathitis ${ }^{1}$, \\ George Kiriakidis ${ }^{1}$ and Vassilios Binas ${ }^{1,2, *(D)}$ \\ 1 Institute of Electronic Structure \& Laser, Foundation for Research and Technology (FORTH-IESL), \\ 71100 Herakleion, Greece; ph4888@edu.physics.uoc.gr (A.P.); vkabitakis@physics.uoc.gr (V.K.); \\ eaper@iesl.forth.gr (E.A.); kiriakid@iesl.forth.gr (G.K.) \\ 2 Department of Physics, University of Crete, 70013 Heraklion, Greece \\ * Correspondence: mgagas@iesl.forth.gr (E.G.); binasbill@iesl.forth.gr (V.B.); Tel.: +30-2810391272 (E.G.); \\ $+30-2810391269$ (V.B.)
}

check for updates

Citation: Paralikis, A.; Gagaoudakis, E.; Kampitakis, V.; Aperathitis, E.; Kiriakidis, G.; Binas, V. Study on the Ozone Gas Sensing Properties of rf-Sputtered Al-Doped NiO Films. Appl. Sci. 2021, 11, 3104. https:// doi.org/10.3390/app11073104

Academic Editor: Stefano Loppi

Received: 10 March 2021

Accepted: 29 March 2021

Published: 31 March 2021

Publisher's Note: MDPI stays neutral with regard to jurisdictional claims in published maps and institutional affiliations.

Copyright: (c) 2021 by the authors. Licensee MDPI, Basel, Switzerland. This article is an open access article distributed under the terms and conditions of the Creative Commons Attribution (CC BY) license (https:// creativecommons.org/licenses/by/ $4.0 /)$.
Featured Application: Authors are encouraged to provide a concise description of the specific application or a potential application of the work. This section is not mandatory.

Abstract: Al-doped $\mathrm{NiO}(\mathrm{NiO}: \mathrm{Al})$ has attracted the interest of researchers due to its excellent optical and electrical properties. In this work, $\mathrm{NiO}: \mathrm{Al}$ films were deposited on glass substrates by the radio frequencies (rf) sputtering technique at room temperature and they were tested against ozone gas. The Oxygen content in $\left(\mathrm{Ar}-\mathrm{O}_{2}\right)$ plasma was varied from $2 \%$ to $4 \%$ in order to examine its effect on the gas sensing performance of the films. The thickness of the films was between $160.3 \mathrm{~nm}$ and $167.5 \mathrm{~nm}$, while the $\mathrm{Al}$ content was found to be between $5.3 \mathrm{at} \%$ and $6.7 \mathrm{at} \%$, depending on the oxygen content in plasma. It was found that $\mathrm{NiO}: \mathrm{Al}$ films grown with $4 \% \mathrm{O}_{2}$ in plasma were able to detect $60 \mathrm{ppb}$ of ozone with a sensitivity of $3.18 \%$ at room temperature, while the detection limit was further decreased to $10 \mathrm{ppb}$, with a sensitivity of $2.54 \%$, at $80{ }^{\circ} \mathrm{C}$, which was the optimum operating temperature for these films. In addition, the films prepared in $4 \% \mathrm{O}_{2}$ in plasma had lower response and recovery time compared to those grown with lower $\mathrm{O}_{2}$ content in plasma. Finally, the role of the operating temperature on the gas sensing properties of the $\mathrm{NiO}$ :Al films was investigated.

Keywords: p-type sensor; Al-doped $\mathrm{NiO}$; rf sputtering; ozone gas sensing

\section{Introduction}

Ozone $\left(\mathrm{O}_{3}\right)$ is a well-known harmful gas existing in the atmosphere as a product of photochemical reactions of Nitrogen dioxide $\left(\mathrm{NO}_{2}\right)$ and/or Volatile Organic Compounds (VOCs), which are very common environmental pollutants that come from industrial activity, cars, etc. [1]. As a result, over $80 \%$ of people live in cities where air pollution is higher than the safety limits of the World Health Organization (WHO) [2]. Taking into account that ozone is associated with various respiratory symptoms, including dyspnea, upper airway irritation, coughing, and chest tightness [1], the need of its detection in outdoor as well as indoor environments becomes of paramount importance.

Various kinds of materials, such as Metal Oxide Semiconductors (MOS) [3-5], inorganic perovskites [6], as well as hybrid perovskites [7] have been examined as gas sensing elements for ozone detection during the last decades. Among them, MOS are by far the most well studied materials for ozone gas sensing applications due to their excellent electrical and optical properties as well as the fact that they can be grown by a number of methods even at large scale $[8,9]$. Nickel oxide $(\mathrm{NiO})$ is a p-type metal oxide semiconductor with a wide energy band gap of 3.4-3.8 eV that has interesting optoelectronic properties [10]. Thus, it can be used in UV photo-detectors [11] as an active material in photovoltaics, such as perovskite or dye-sensitized solar cells [12-16], as well as in electrochromic [17], 
thermoelectric [18], and gas sensing devices for the detection of gases, such as $\mathrm{H}_{2}[19,20]$, $\mathrm{CH}_{4}$ [21], $\mathrm{NO}_{2}$ [22], ethanol [23], $\mathrm{O}_{3}$ [24], etc. Furthermore, the introduction of Aluminum (Al) atoms in the $\mathrm{NiO}$ structure seems to enhance its electrical as well as optical properties [25], while not affecting its gas sensing performance. As a result, Al-doped $\mathrm{NiO}$ films have been already tested against $\mathrm{NO}_{2}$ [26,27], ethanol [28], $\mathrm{CO}$ [29], $\mathrm{H}_{2}$, and $\mathrm{CH}_{4}$ [30]. However, $\mathrm{NiO}: \mathrm{Al}$ films have not been examined for ozone detection, according to our literature research.

In this work, rf-sputtered $\mathrm{Al}$-doped $\mathrm{NiO}$ films were tested, for first time, against ozone. The effect of Oxygen content in $\mathrm{Ar}-\mathrm{O}_{2}$ plasma as well as the operating temperature on the gas sensing performance were studied. It was found that $\mathrm{NiO}$ : $\mathrm{Al}$ films have the ability to detect ozone even at room temperature, while those prepared with $4 \% \mathrm{O}_{2}$ in plasma successfully detected ozone at an ultra-low concentration of $10 \mathrm{ppb}$ at $80^{\circ} \mathrm{C}$. The latter is one of the lower operating temperatures for metal oxide gas sensors.

\section{Materials and Methods}

\subsection{Deposition Conditions}

A Nordiko RFG2500 rf sputtering system was employed to grow NiO:Al films using a $\mathrm{Ni}$ metal target and $\mathrm{Ar}-\mathrm{O}_{2}$ air mixture in plasma. Two (2) Al pellets were placed on the $\mathrm{Ni}$ target surface for $\mathrm{Al}$-doping. Both pressure and sputtering power were kept constant during deposition, being 5 mTorr and $300 \mathrm{~W}$, respectively. The films were deposited on three different substrates, namely the commercial (Metrohm/DropSens) InterDigitated Transducers (glass substrate, Pt electrodes, bands/gaps $=5 \mu \mathrm{m}$ ) for sensing measurements, a piece of silicon wafer for structural characterization, and microscope glass for optical measurements. All depositions were done at room temperature (RT). The $\mathrm{O}_{2}$ content in plasma was varied, being $2.0 \%, 2.8 \%$, and $4.0 \%$ in order to examine its effect on the gas sensing characteristics of the films. After deposition, the films underwent thermal annealing at $400{ }^{\circ} \mathrm{C}$ under air for $24 \mathrm{~h}$, in order to improve both their crystallinity and optical properties.

\subsection{Characterization}

The structure of the Al-doped $\mathrm{NiO}$ films was examined by the X-ray Diffraction (XRD) technique, using a PANalyticalEmpyrean diffractometer equipped with Cu-LFF as an $X$-Ray source, at $\lambda=0.15406 \mathrm{~nm}$. The measurement mode was $2 \theta / \theta$ varying from $20^{\circ}$ to $90^{\circ}$, with a step of $0.013^{\circ} / \mathrm{s}$. Using the XRD pattern the crystallite size (D) of the films was calculated according to Scherrer's Equation (1)

$$
\mathrm{D}(\mathrm{nm})=(0.9 \cdot \lambda) /(\mathrm{B} \cdot \cos \theta)
$$

where $\lambda$ is the $X$-ray wavelength which equals to $0.154 \mathrm{~nm}$. B is the Full Width at Half Maximum (FWHM) of the corresponding peak at an angle 20. Moreover, the lattice constant $\left(\mathrm{a}_{0}\right)$ for the cubic structure of $\mathrm{NiO}$ was calculated according to Equation (2)

$$
\mathrm{a}=\left(\mathrm{h}^{2}+\mathrm{k}^{2}+\ell^{2}\right)^{1 / 2} / \mathrm{d}
$$

where $\mathrm{d}$ is the distance between the adjacent planes in the set (hk $\ell$ ). Field Emission Surface Electron Microscopy (FESEM) was used to investigate the surface morphology of the films using a Hitachi S570 microscope, equipped with an Energy Dispersive X-ray (EDX) spectrometry system, which was employed to determine the $\mathrm{Al}$ at $\%$ of the $\mathrm{NiO}: \mathrm{Al}$ films. Optical properties of the films were studied with a Perkin Elmer Lambda 950 UV/Vis/NIR spectrophotometer in the wavelength range of $250-2500 \mathrm{~nm}$. The transmittance spectra and the corresponding Tauc plot were used in order to calculate the optical energy bandgap of the films assuming that direct transitions are permitted according to Equation (3)

$$
(\alpha h v)=A\left(h v-E_{g}\right)^{1 / 2}
$$


where $\alpha$ is the absorption coefficient, hv the photon energy, A is a constant and $E_{g}$ the optical energy bandgap. The thickness of the films was measured by using a Veeco Dektak 150 stylus profilometer.

\subsection{Gas Sensing}

In order to investigate the gas sensing performance in ozone, the $\mathrm{NiO}: \mathrm{Al}$ films deposited on IDTs were placed in a homemade stainless steel test chamber. A mechanical pump was used to initially evacuate the chamber, while an FP-400 temperature controller was employed to regulate the operating temperature. Ozone of different concentrations was produced by an ozone analyzer (Thermo, Model 49i, Thermofisher scientific, Waltham, MA, USA). A Keithley 6517A electrometer was used to apply a constant voltage on the films and measure the electrical current variations upon the interaction between the film and the target gas. The chamber was initially evacuated at a pressure of $1 \mathrm{mbar}$. Prior to the ozone exposure, the films were treated with synthetic (dry) air for $45 \mathrm{~min}$ in order to be stabilized in the testing environment. After that, the films were exposed to ozone of specific concentrations for a constant time duration in which the electrical current was increased, while the recovery of the films in its initial state was done by exposing them in synthetic air for a specific time period. Both ozone and synthetic air were introduced in the chamber with a flow of $200 \mathrm{sccm}$ (standard cubic centimeters per minute) regulated by mass flow controllers, while the pressure in the chamber was kept constant of 700 mbar. The whole procedure was monitored by a PC through an appropriate LabVIEW program. The sensitivity (S) of the sensor is defined by the following Equation (4)

$$
\mathrm{S}(\%)=\left[\left(\mathrm{I}_{\text {gas }}-\mathrm{I}_{\text {air }}\right) / \mathrm{I}_{\text {air }}\right] \cdot 100 \%
$$

where $I_{\text {gas }}$ is the maximum value of electrical current in the presence of ozone, while $\mathrm{I}_{\text {air }}$ is the minimum value of electrical current in the presence of synthetic air (absence of ozone), as depicted in Figure 1. Moreover, the response time $\left(t_{\text {resp }}\right)$ is defined as the time that is needed for the electrical current to become equal to the $90 \%$ of the value of $\mathrm{I}_{\text {gas }}$ in the presence of ozone, while the recovery time $\left(\mathrm{t}_{\mathrm{rec}}\right)$ is defined as the required time for the electrical current to be equal to $10 \%$ of the value of $I_{\text {gas }}$ in the absence of ozone (in the presence of synthetic air).

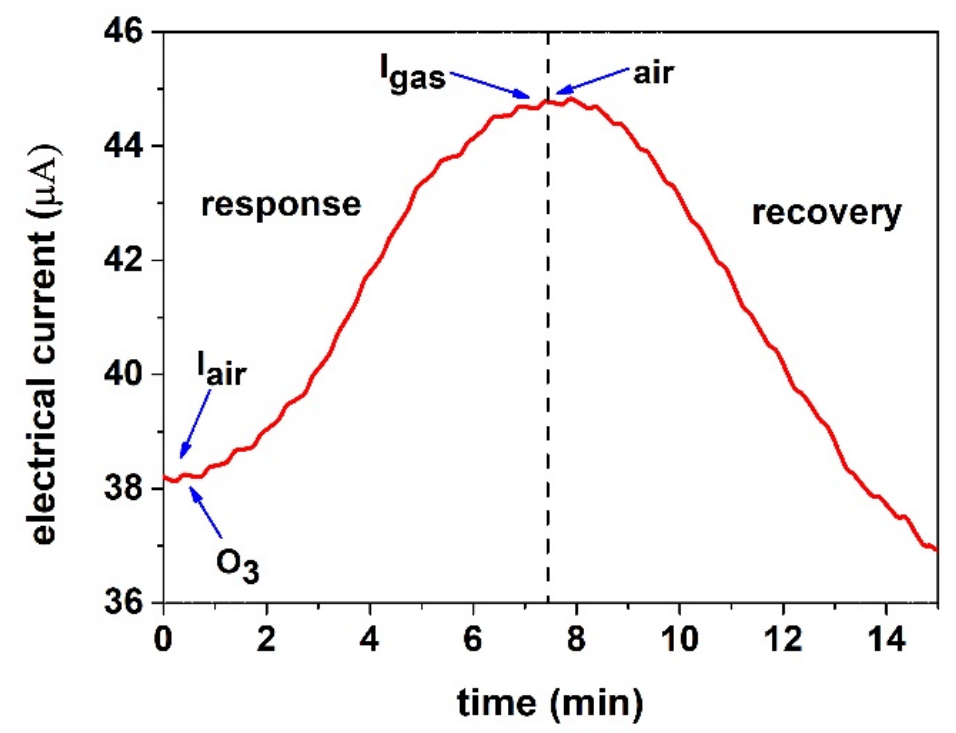

Figure 1. Typical sensing measurement of an $\mathrm{O}_{3}$-synthetic air cycle.

All measurements were taken under the room relative humidity $(\mathrm{RH})$ which was about $60 \%$. 


\section{Results and Discussion}

\subsection{Characterization}

The XRD patterns of rf-sputtered Al-doped $\mathrm{NiO}$ films deposited on Si substrates at room temperature with different $\mathrm{O}_{2}$ content in plasma that underwent thermal annealing at $400{ }^{\circ} \mathrm{C}$ for $24 \mathrm{~h}$ are presented in Figure 2. It can be seen that all films had a polycrystalline structure with a peak of high intensity at $2 \theta=43.3^{\circ}$ corresponding to a reflection from the (200) planes and two low intensity peaks at $2 \theta=36.5^{\circ}$ and $62.9^{\circ}$ corresponding to reflections from the (111) and (220) planes, respectively, according to JCPDS Card No. 047-1049. No peaks corresponding to other materials were found, indicating that all $\mathrm{Al}$ atoms were introduced in the $\mathrm{NiO}$ structure. Using Equation (1) for the diffraction peak with the highest intensity (200), the crystallite size of the films was calculated (Table 1) and found to be between $8.68 \mathrm{~nm}$ for films prepared with $2 \%$ and $2.8 \% \mathrm{O}_{2}$ in plasma and $7.89 \mathrm{~nm}$ for those prepared with $4 \% \mathrm{O}_{2}$ in plasma. In the case of the films prepared with $4 \% \mathrm{O}_{2}$, the decrease of the crystallite size may lead to a further increase of defect states inside the crystal structure, which can also be observed through the intensity of the main peak. In addition, the lattice constant $\left(\mathrm{a}_{0}\right)$ of the films was calculated from Equation (2) and was varied between $0.417 \mathrm{~nm}$ and $0.421 \mathrm{~nm}$ (Table 1). Both the crystallite size and lattice constant are in agreement with the values reported in the literature for Al-doped $\mathrm{NiO}$ films prepared by various techniques $[25,31]$.

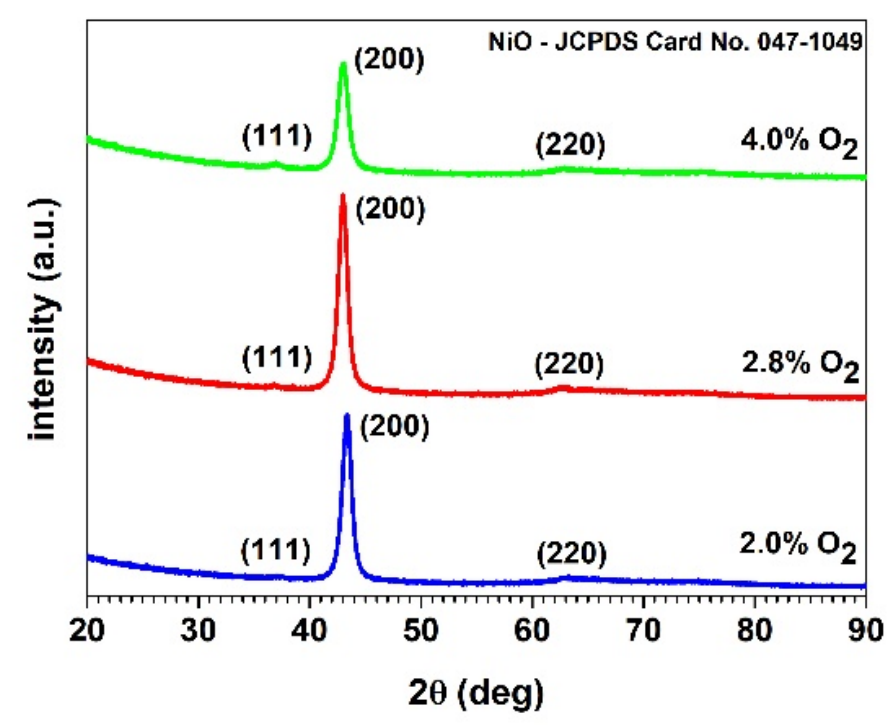

Figure 2. X-ray Diffraction (XRD) patterns of rf-sputtered NiO:Al films grown at room temperature with different $\mathrm{O}_{2}$ content in plasma that underwent thermal annealing at $400{ }^{\circ} \mathrm{C}$ for $24 \mathrm{~h}$.

Table 1. Deposition parameters, thickness ( $\mathrm{t})$, crystallite size (D), lattice constant $\left(\mathrm{a}_{0}\right)$, and optical energy bandgap $\left(\mathrm{E}_{\mathrm{g}}\right)$ of rf-sputtered $\mathrm{Al}$-doped $\mathrm{NiO}$ films.

\begin{tabular}{ccccccc}
\hline $\begin{array}{c}\text { Sample } \\
\text { No. }\end{array}$ & $\begin{array}{c}\text { \% } \mathbf{O}_{\mathbf{2}} \\
\text { in Plasma }\end{array}$ & $\begin{array}{c}\text { \%at. } \\
\mathbf{A l}\end{array}$ & $\begin{array}{c}\mathbf{t} \\
\mathbf{( n m )}\end{array}$ & $\begin{array}{c}\mathbf{D} \\
\mathbf{( n m )}\end{array}$ & $\begin{array}{c}\mathbf{a}_{\mathbf{0}} \\
(\mathbf{n m})\end{array}$ & $\begin{array}{c}\mathbf{E}_{\mathbf{g}} \\
(\mathbf{e V})\end{array}$ \\
\hline $\mathrm{S} 1749$ & 2.0 & 5.3 & 160.3 & 8.68 & 0.417 & 3.66 \\
$\mathrm{~S} 1746$ & 2.8 & 6.5 & 168.7 & 8.68 & 0.421 & 3.65 \\
$\mathrm{~S} 1743$ & 4.0 & 6.7 & 167.5 & 7.89 & 0.420 & 3.66 \\
\hline
\end{tabular}

The surface morphology of the $\mathrm{NiO}: \mathrm{Al}$ films is presented in Figure 3a-c. It can be seen that all films had a smooth and uniform surface consisting of grains with a diameter of around $40 \mathrm{~nm}$ The increased defects on the surface of the film prepared with $4 \% \mathrm{O}_{2}$ can be also be observed. 


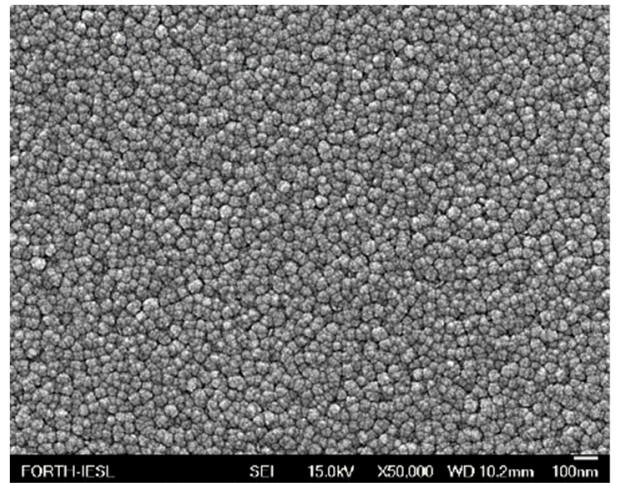

(a) $2.0 \%$

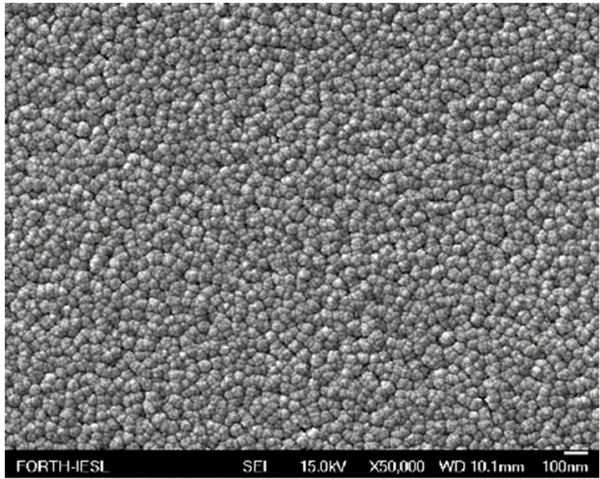

(b) $2.8 \%$

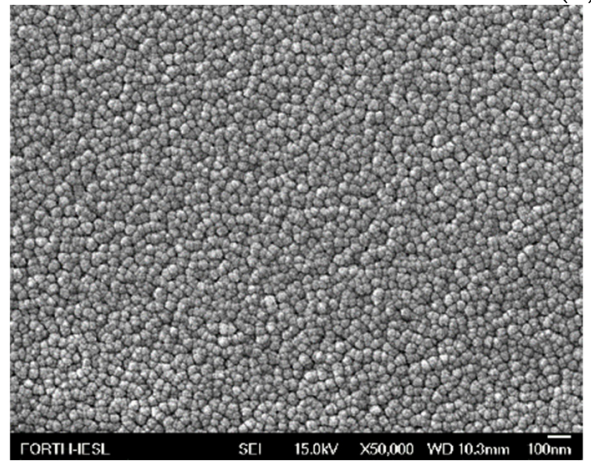

(c) $4.0 \%$

Figure 3. SEM images of rf-sputtered NiO:Al films grown at room temperature with (a) $2.0 \%$, (b) $2.8 \%$, and (c) $4.0 \% \mathrm{O}_{2}$ content in plasma that underwent thermal annealing at $400{ }^{\circ} \mathrm{C}$ for $24 \mathrm{~h}$.

The transmittance spectra of the Al-doped $\mathrm{NiO}$ films are shown in Figure 4. All films were highly transparent $(>70 \%)$ in the visible region as well as in the near infrared one. Using Equation (3) and the Tauc plot (inset of Figure 4), the optical energy bandgap was calculated and found to be around $3.66 \mathrm{eV}$ (Table 1), comparable with the values reported by Chattopadhyay et al. for Al-doped $\mathrm{NiO}$ films grown by the rf sputtering technique [25].

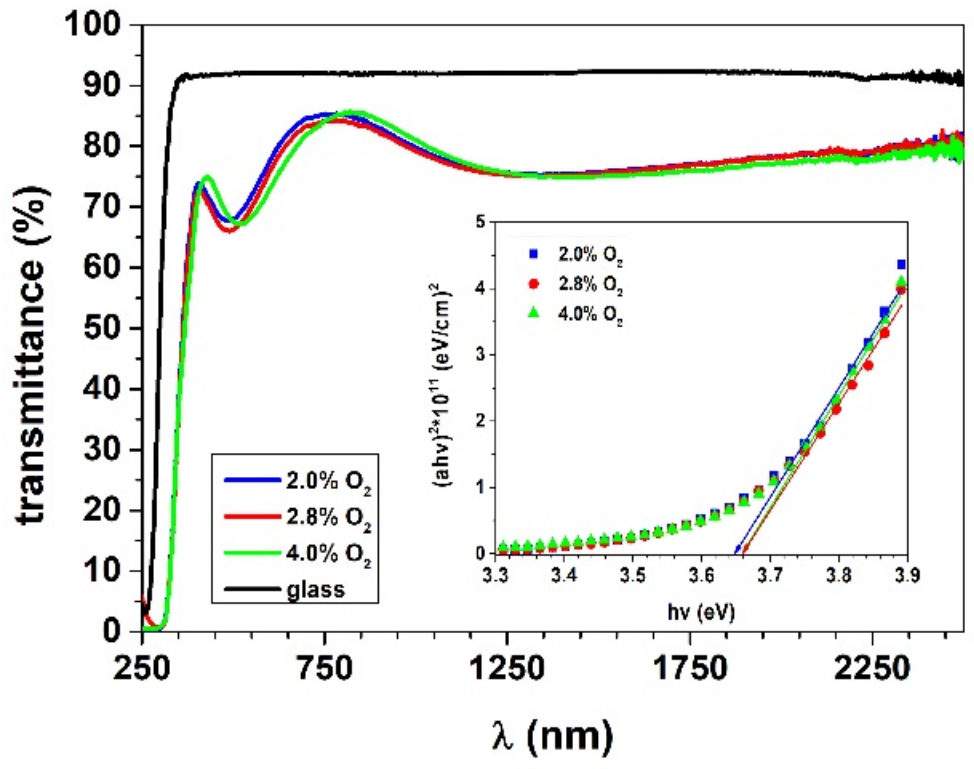

Figure 4. Transmittance spectra of rf-sputtered NiO:Al films grown at room temperature with different $\mathrm{O}_{2}$ content in plasma that underwent thermal annealing at $400{ }^{\circ} \mathrm{C}$ for $24 \mathrm{~h}$. Inset: Tauc plot to determine the optical energy band gap of the films. 


\subsection{Gas Sensing}

The gas sensing performance of rf-sputtered $\mathrm{Al}$-doped $\mathrm{NiO}$ films was investigated by exposing them to ozone gas with a concentration varying from $10 \mathrm{ppb}$ to $3000 \mathrm{ppb}$, at operating temperatures between $\mathrm{RT}$ and $150{ }^{\circ} \mathrm{C}$. The duration in ozone exposure was $5 \mathrm{~min}$ for films prepared with $4 \% \mathrm{O}_{2}$ in plasma and $10 \mathrm{~min}$ for the films prepared with $2 \%$ and $2.8 \% \mathrm{O}_{2}$ in plasma, while the recovery of the sensors was carried out by exposing them to synthetic air for $10 \mathrm{~min}$ and $15 \mathrm{~min}$, respectively. The applied voltage was $10 \mathrm{~V}$ when the operating temperature equals to RT, while for the rest of the operating temperatures the applied voltage was $1 \mathrm{~V}$.

A typical measurement of electrical current variation for different $\mathrm{O}_{3}$ concentrations is presented in Figure 5. In the presence of ozone the electrical current of the film is increased reaching a maximum value, while in the absence of the target gas the electrical current of the film is decreased, as a result of its interaction with synthetic air, reaching its initial value. Moreover, it is noted that the sensor cannot be fully recovered to its initial electrical current value, especially at high concentrations ( $>600 \mathrm{ppb})$, probably due to residual oxidation. The gas sensing mechanism for $\mathrm{Al}$-doped $\mathrm{NiO}$ films is the typical one for a p-type semiconductor. Thus, upon the exposure to synthetic air, Oxygen species $(\mathrm{O}$, $\mathrm{O}^{2-}$, etc.) are formed as a result of the $\mathrm{O}_{2}$ adsorption on the films' surface. This is described through the following Equations (5)-(7).

$$
\begin{gathered}
\mathrm{O}_{2(\text { gas })}+\mathrm{e}^{-} \rightarrow \mathrm{O}_{2 \text { (adsorbed) }}^{-} \\
\mathrm{O}_{2(\text { gas })}+2 \mathrm{e}^{-} \rightarrow 2 \mathrm{O}_{(\text {adsorbed })}^{-} \\
\mathrm{O}_{2 \text { (adsorbed) }}^{-}+\mathrm{e}^{-} \rightarrow \mathrm{O}_{(\text {adsorbed })}^{2-}
\end{gathered}
$$

where the kind of oxygen ions is dependent on the operating temperature $\left(\mathrm{T}_{\mathrm{oper}}\right)$, being $\mathrm{O}_{2}^{-}$for $\mathrm{T}_{\text {oper }}<100{ }^{\circ} \mathrm{C}, \mathrm{O}^{-}$for $100{ }^{\circ} \mathrm{C}<\mathrm{T}_{\text {oper }}<300{ }^{\circ} \mathrm{C}$, and $\mathrm{O}^{2-}$ for $\mathrm{T}_{\text {oper }}>300{ }^{\circ} \mathrm{C}$. The Oxygen species take out electrons from $\mathrm{NiO}$, increasing the number of holes, leading to an increase of electrical conductivity, thus a depletion layer is formed. As a result, the height of the potential barrier at the grain boundaries is decreased and the electrical current is slightly increased. When NiO:Al films interact with ozone, which is a strongly oxidizing gas, the ozone molecules are adsorbed on the films' surface trapping the free electrons, resulting in an increase of the hole concentration as well as in a decrease of the thickness of the depletion layer. Thus, an extra increase of the electrical current is occurred [32,33].

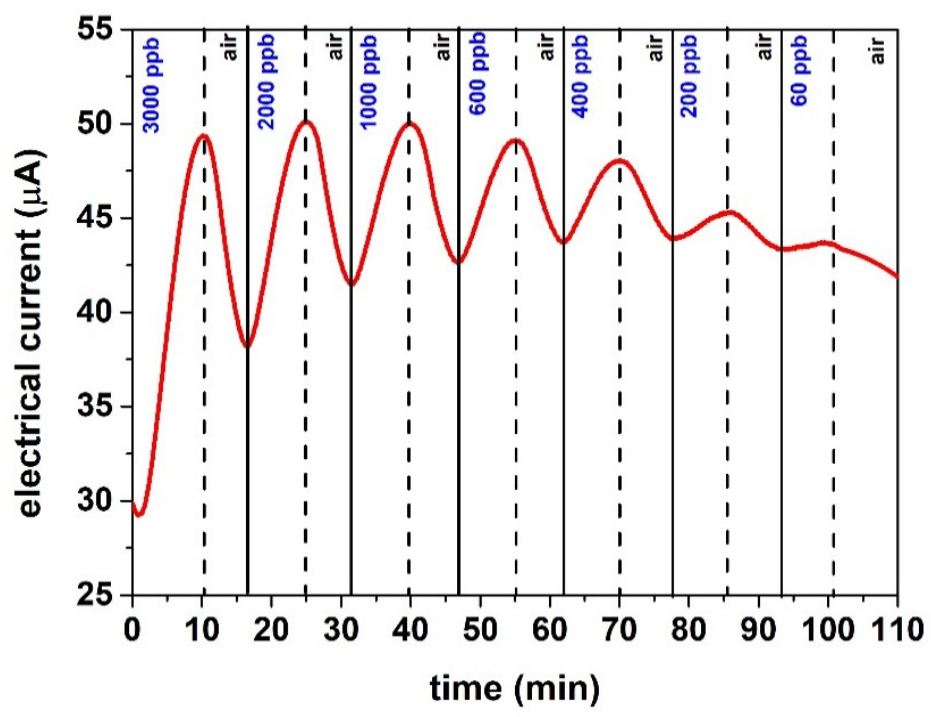

Figure 5. Electrical current variation of a $\mathrm{NiO}$ : Al film prepared with $4 \% \mathrm{O}_{2}$ in plasma, as a function of time for different $\mathrm{O}_{3}$ concentrations, at $110{ }^{\circ} \mathrm{C}$. 
In Figure 6a-c the variation in sensitivity of the NiO:Al films grown with different $\mathrm{O}_{2}$ content in plasma are shown. This was calculated by Equation (4) as a function of ozone concentration for various operating temperatures and plotted in logarithmic scale. In addition, a linear fitting has been applied confirming that the sensitivity is increased with $\mathrm{O}_{3}$ concentration, independent of the Oxygen content in the plasma or the operating temperature. From Figure 6, it becomes clear that all films can detect the ozone gas even at an ultra-low concentration of $10 \mathrm{ppb}$. Specifically, the films prepared with $2 \% \mathrm{O}_{2}$ in plasma had a lowest detection limit of around $200 \mathrm{ppb}$ with a sensitivity $1.88 \%, 11.31 \%$ and $38.66 \%$ at $\mathrm{RT}, 110^{\circ} \mathrm{C}$ and $150{ }^{\circ} \mathrm{C}$, respectively, while at $80^{\circ} \mathrm{C}$ the lowest detection limit was $400 \mathrm{ppb}$ with a sensitivity of $5.17 \%$. Moreover, films synthesized with $2.8 \% \mathrm{O}_{2}$ in plasma had a lowest detection limit of $400 \mathrm{ppb}$ [27] (sensitivity 0.84\%), $200 \mathrm{ppb}$ (sensitivity 6.25\%), $200 \mathrm{ppb}$ (sensitivity 6.94\%) and $60 \mathrm{ppb}$ (sensitivity 6.22\%) when the operating temperature equals to RT, $80^{\circ} \mathrm{C}, 110{ }^{\circ} \mathrm{C}$, and $150{ }^{\circ} \mathrm{C}$, respectively. Finally, the NiO:Al prepared with $4 \% \mathrm{O}_{2}$ in plasma appeared to have a lowest detection limit of $60 \mathrm{ppb}$ (sensitivity $3.18 \%$ ), $10 \mathrm{ppb}$ (sensitivity 2.54\%), $60 \mathrm{ppb}$ (sensitivity $2.44 \%$ ) and $400 \mathrm{ppb}$ (sensitivity $9.02 \%$ ) when the operating temperature equals to $\mathrm{RT}, 80^{\circ} \mathrm{C}, 110^{\circ} \mathrm{C}$, and $150{ }^{\circ} \mathrm{C}$. The detection limit of $10 \mathrm{ppb}$ at $80^{\circ} \mathrm{C}$ is one order of magnitude less than the one that has been reported [32] for $\mathrm{Co}_{3} \mathrm{O}_{4}$ nanobricks at almost the same working temperature $\left(85^{\circ} \mathrm{C}\right)$. The above mentioned values for all NiO:Al films are presented in Table 2.

Furthermore, in Figure 7 the effect of the operating temperature on gas sensing performance of the rf-sputtered $\mathrm{NiO}: \mathrm{Al}$ films is shown. The films tested against $400 \mathrm{ppb}$ ozone at various operating temperatures, namely $\mathrm{RT}, 80^{\circ} \mathrm{C}, 110^{\circ} \mathrm{C}$, and $150{ }^{\circ} \mathrm{C}$. It can be seen that films prepared with $4 \% \mathrm{O}_{2}$ in plasma appeared to have the best sensitivity at $80^{\circ} \mathrm{C}$, while the rest of them showed a maximum sensitivity at $150{ }^{\circ} \mathrm{C}$. This can be attributed to both less $\mathrm{Al}$ content and smaller crystallite size of the films grown with $4 \%$ $\mathrm{O}_{2}$ in plasma compared to the others, which also leads to a further decrease of the defect states that can reduce the adsorption energy of the $\mathrm{O}_{3}$ gas molecules [34]. In addition, the operating temperature of $80^{\circ} \mathrm{C}$ is one of the lowest that has been reported for ultra-low ozone concentration $(10 \mathrm{ppb})$ [4,32].

Finally, the response and recovery time of the $\mathrm{NiO}$ :Al films for each operating temperature were calculated and presented in Figure $8 \mathrm{a}-\mathrm{c}$. Films grown with $2 \%$ and $2.8 \%$ $\mathrm{O}_{2}$ in plasma had a response time between $400 \mathrm{~s}$ and $800 \mathrm{~s}$, depending on both operating temperature and ozone concentration, while for those prepared with $4 \% \mathrm{O}_{2}$ in plasma the response time was ranging from $150 \mathrm{~s}$ to $500 \mathrm{~s}$. In the same way, the recovery time for the former films was between $400 \mathrm{~s}$ and $900 \mathrm{~s}$, while it was varied from $200 \mathrm{~s}$ to $600 \mathrm{~s}$ for films grown with $4 \% \mathrm{O}_{2}$ in plasma. It should be noticed that the $\mathrm{Al}$ : $\mathrm{NiO}$ films grown with $4 \%$ $\mathrm{O}_{2}$ in plasma showed the best response and the recovery time equals to $189.6 \mathrm{~s}$ and $243.6 \mathrm{~s}$, respectively, against $10 \mathrm{ppb}$ ozone at an operating temperature of $80^{\circ} \mathrm{C}$. The response time values of $\mathrm{Al}: \mathrm{NiO}$ films are higher than those in other reported works, while the recovery time values are comparable to those reported in the literature [4,32,34-38]. However, most of these sensors work at higher temperatures and/or have a higher concentration detection limit than those presented in this work. 

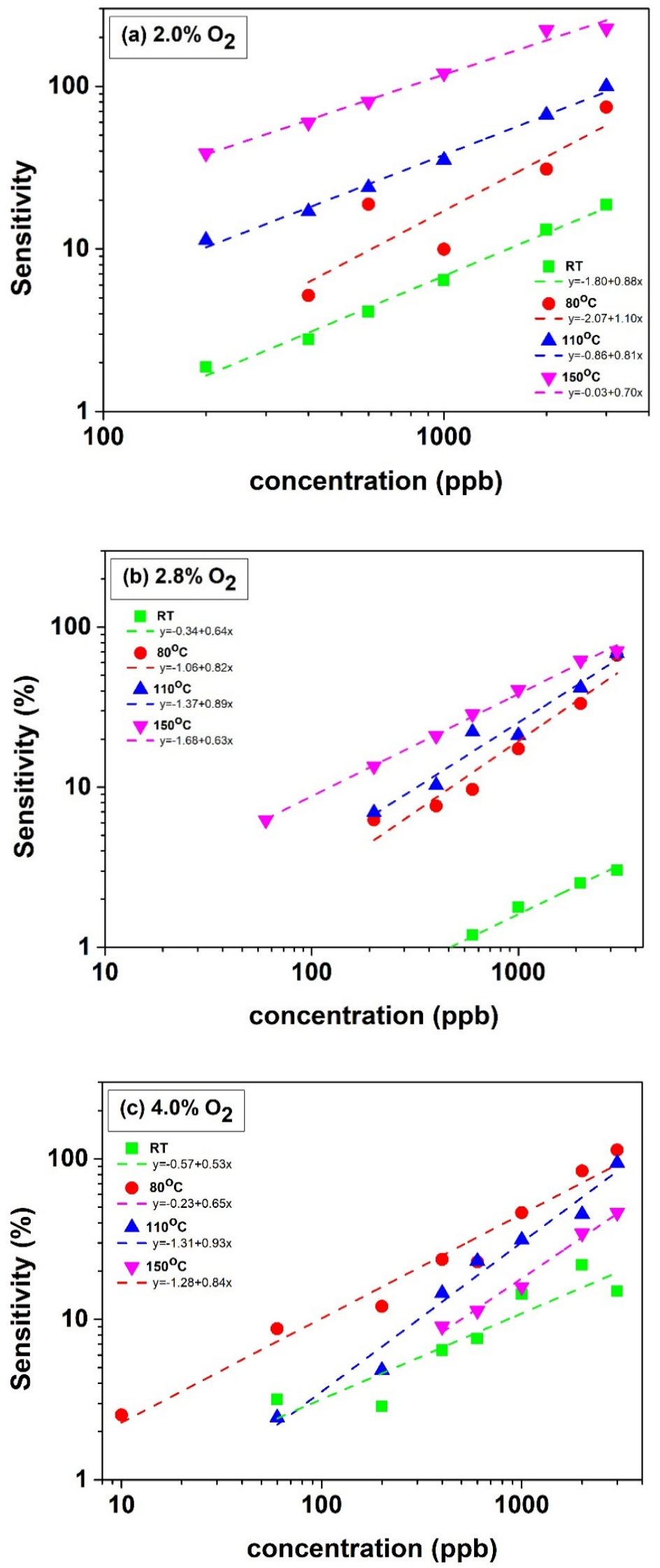

Figure 6. Sensitivity on different ozone concentrations at various operating temperatures of rf-sputtered $\mathrm{NiO}$ :Al with (a) $2.0 \%$, (b) $2.8 \%$, and (c) $4.0 \% \mathrm{O}_{2}$ in plasma. A linear fitting plot has been applied. 
Table 2. Deposition parameters, temperature of operation $\left({ }^{\circ} \mathrm{C}\right)$, minimum detection concentration $(\mathrm{ppb})$, and sensitivity $(\mathrm{S})$ of rf-sputtered Al-doped $\mathrm{NiO}$ films.

\begin{tabular}{|c|c|c|c|c|}
\hline Sample No. & $\begin{array}{c}\% \mathrm{O}_{2} \\
\text { in Plasma }\end{array}$ & $\mathrm{T}_{\text {oper }}\left({ }^{\circ} \mathrm{C}\right)$ & $\begin{array}{l}\text { Minimum Detected } \\
\text { Concentration }(p p b)\end{array}$ & $\mathrm{S}(\%)$ \\
\hline \multirow{4}{*}{ S1749 } & \multirow{4}{*}{2.0} & $\mathrm{RT}$ & 213 & 1.88 \\
\hline & & 80 & 393 & 5.17 \\
\hline & & 110 & 213 & 11.31 \\
\hline & & 150 & 207 & 38.66 \\
\hline \multirow{4}{*}{ S1746 } & \multirow{4}{*}{2.8} & RT & 393 & 0.84 \\
\hline & & 80 & 212 & 6.25 \\
\hline & & 110 & 215 & 6.94 \\
\hline & & 150 & 67 & 6.22 \\
\hline \multirow{4}{*}{ S1743 } & \multirow{4}{*}{4.0} & RT & 58 & 3.18 \\
\hline & & 80 & 13 & 2.54 \\
\hline & & 110 & 59 & 2.44 \\
\hline & & 150 & 330 & 9.02 \\
\hline
\end{tabular}

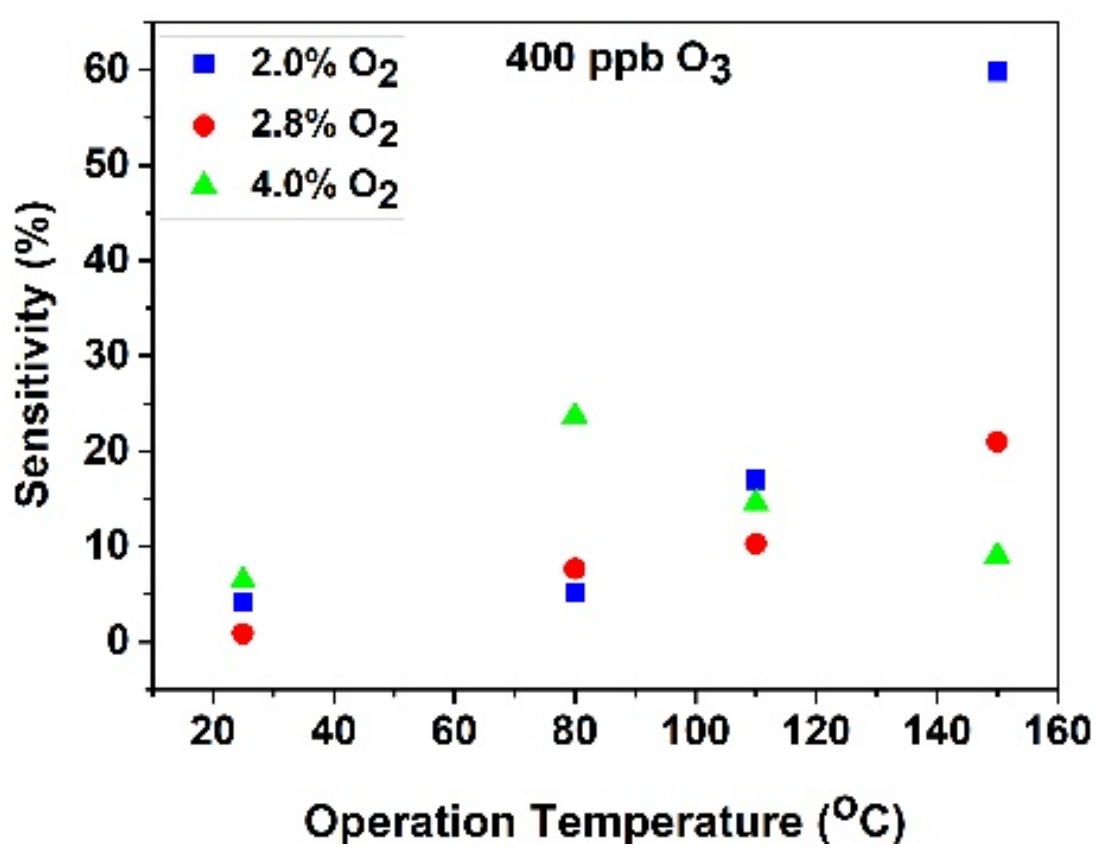

Figure 7. Sensitivity of rf-sputtered $\mathrm{NiO}$ :Al films grown with different $\mathrm{O}_{2}$ content in plasma as a function of operating temperature. 
(a) $2.0 \% \mathrm{O}_{2}$

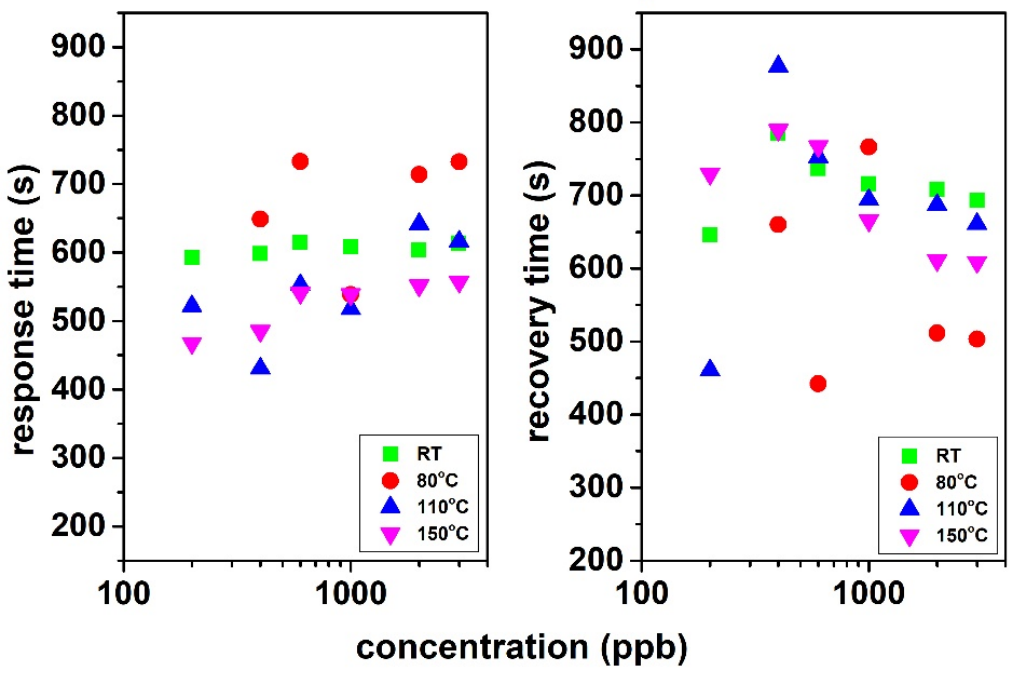

(b) $2.8 \% \mathrm{O}_{2}$

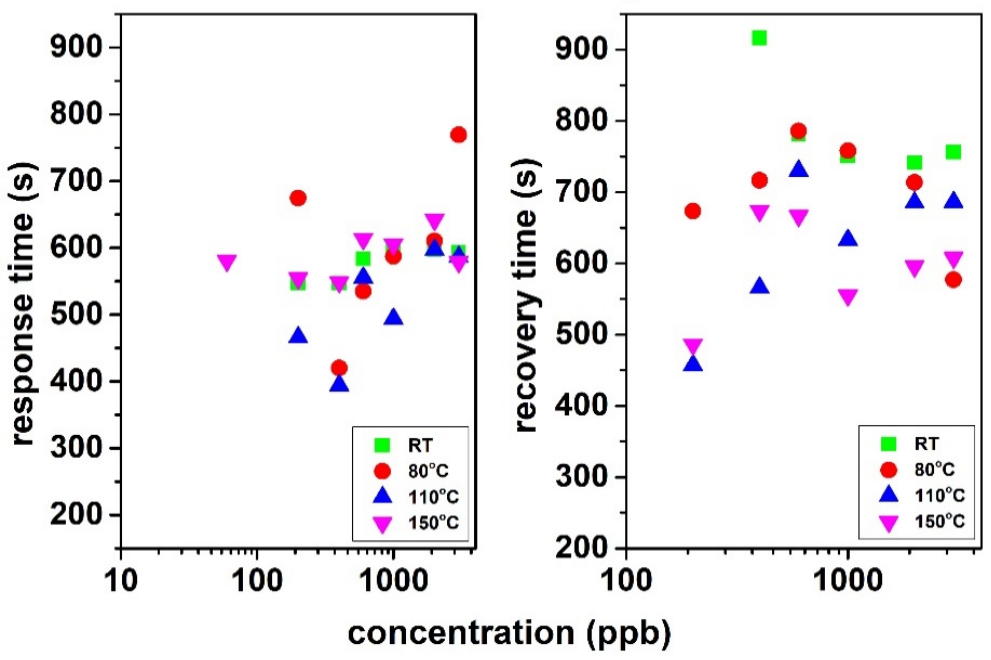

(c) $4.0 \% \mathrm{O}_{2}$

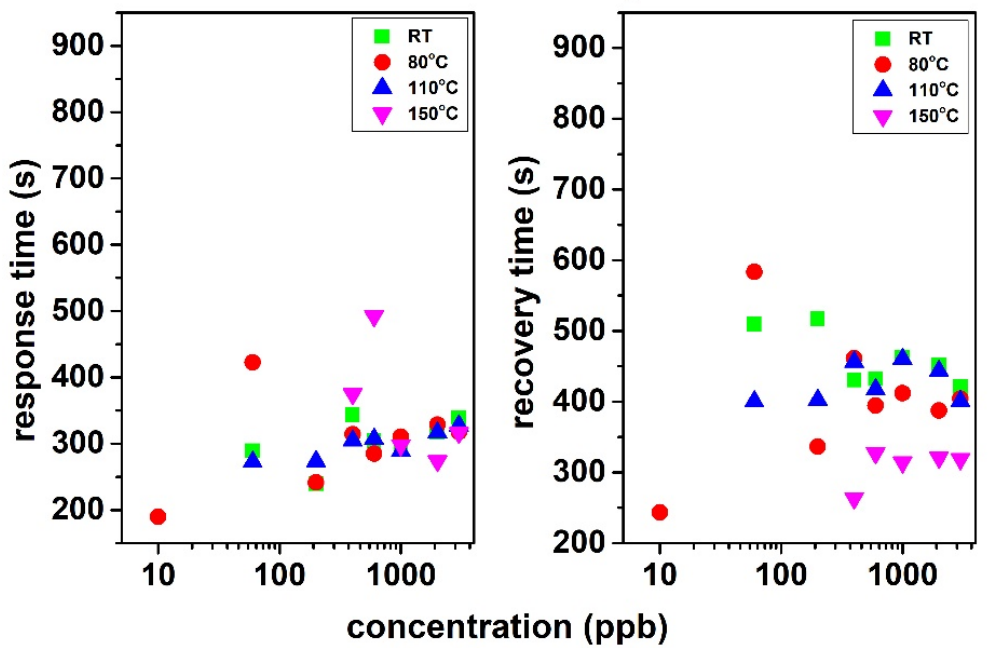

Figure 8. Response and recovery times at different operating temperatures of rf-sputtered $\mathrm{NiO}: \mathrm{Al}$ with (a) $2.0 \%$, (b) $2.8 \%$, and (c) $4.0 \% \mathrm{O}_{2}$ in plasma as a function of ozone concentrations. 


\section{Conclusions}

Al-doped $\mathrm{NiO}$ films were grown by the rf sputtering technique with different oxygen contents in $\mathrm{Ar}-\mathrm{O}_{2}$ plasma, i.e., $2 \%, 2.8 \%$, and $4 \%$, at room temperature. All films were polycrystalline as revealed by the XRD technique, while their surface was smooth as was confirmed by Scanning Electron Microscopy. Moreover, all films were highly transparent, showing a transmittance of more than $70 \%$ in the visible spectrum. The gas sensing performance of the films against ozone was studied at different operating temperatures, namely $25^{\circ} \mathrm{C}, 80^{\circ} \mathrm{C}, 110{ }^{\circ} \mathrm{C}$, and $150^{\circ} \mathrm{C}$. All films were sensitive to ozone of different concentrations. Specifically, films grown with $4 \% \mathrm{O}_{2}$ in plasma were able to detect ozone at an ultra-low concentration of $10 \mathrm{ppb}$ at a low operating temperature of $80^{\circ} \mathrm{C}$. Thus NiO:Al films can be potentially used as a sensing element for ozone gas sensors.

Author Contributions: Conceptualization, A.P. and V.K.; methodology, E.G.; data curation, E.G.; writing — original draft preparation, E.G.; writing—review and editing, V.B., G.K. and E.A.; supervision, E.G.; project administration, V.B. All authors have read and agreed to the published version of the manuscript.

Funding: Part of this work supported by the project "Quality of Life" (MIS 5002464) which is implemented under the "Action for the Strategic Development on the Research and Technological Sector", funded by the Operational Programme "Competitiveness, Entrepreneurship and Innovation" (NSRF 2014-2020) and co-financed by Greece and the European Union (European Regional Development Fund).

Institutional Review Board Statement: Not applicable.

Informed Consent Statement: Not applicable.

Data Availability Statement: Not applicable.

Conflicts of Interest: The authors declare no conflict of interest.

\section{References}

1. Huangfu, P.; Atkinson, R. Long-term exposure to $\mathrm{NO}_{2}$ and $\mathrm{O}_{3}$ and all-cause and respiratory mortality: A systematic review and meta-analysis. Environ. Int. 2020, 144, 105998. [CrossRef]

2. $\quad$ Barkjohn, K.K.; Norris, C.; Cui, X.; Fang, L.; Zheng, T.; Schauer, J.J.; Li, Z.; Zhang, Y.; Black, M.; Zhang, J.; et al. Real-time measurements of PM 2.5 and ozone to assess the effectiveness of residential indoor air filtration in Shanghai homes. Indoor Air 2021, 31, 74-87. [CrossRef]

3. Bejaoui, A.; Guerin, J.; Zapien, J.; Aguir, K. Theoretical and experimental study of the response of CuO gas sensor under ozone. Sens. Actuators B Chem. 2014, 190, 8-15. [CrossRef]

4. Rocha, L.; Foschini, C.; Silva, C.; Longo, E.; Simões, A. Novel ozone gas sensor based on ZnO nanostructures grown by the microwave-assisted hydrothermal route. Ceram. Int. 2016, 42, 4539-4545. [CrossRef]

5. Petromichelaki, E.; Gagaoudakis, E.; Moschovis, K.; Tsetseris, L.; Anthopoulos, T.D.; Kiriakidis, G.; Binas, V. Highly sensitive and room temperature detection of ultra-low concentrations of $\mathrm{O}_{3}$ using self-powered sensing elements of $\mathrm{Cu}_{2} \mathrm{O}$ nanocubes. Nanoscale Adv. 2019, 1, 2009-2017. [CrossRef]

6. Brintakis, K.; Gagaoudakis, E.; Kostopoulou, A.; Faka, V.; Argyrou, A.; Binas, V.; Kiriakidis, G.; Stratakis, E. Ligand-free allinorganic metal halide nanocubes for fast, ultra-sensitive and self-powered ozone sensors. Nanoscale Adv. 2019, 1, $2699-2706$. [CrossRef]

7. Kakavelakis, G.; Gagaoudakis, E.; Petridis, K.; Petromichelaki, V.; Binas, V.; Kiriakidis, G.; Kymakis, E. Solution Processed CH3NH3PbI3-xClxPerovskite Based Self-Powered Ozone Sensing Element Operated at Room Temperature. ACS Sens. 2018, 3, 135-142. [CrossRef] [PubMed]

8. Wetchakun, K.; Samerjai, T.; Tamaekong, N.; Liewhiran, C.; Siriwong, C.; Kruefu, V.; Wisitsoraat, A.; Tuantranont, A.; Phanichphant, S. Semiconducting metal oxides as sensors for environmentally hazardous gases. Sens. Actuators B Chem. 2011, 160, 580-591. [CrossRef]

9. Moseley, P.T. Progress in the development of semiconducting metal oxide gas sensors: A review. Meas. Sci. Technol. 2017, 28, 082001. [CrossRef]

10. Reddy, A.M.; Reddy, A.S.; Lee, K.-S.; Reddy, P.S. Effect of oxygen partial pressure on the structural, optical and electrical properties of sputtered $\mathrm{NiO}$ films. Ceram. Int. 2011, 37, 2837-2843. [CrossRef]

11. Echresh, A.; Chey, C.O.; Shoushtari, M.Z.; Khranovskyy, V.; Nour, O.; Willander, M. UV photo-detector based on p-NiO thin film/n-ZnO nanorods heterojunction prepared by a simple process. J. Alloys Compd. 2015, 632, 165-171. [CrossRef] 
12. Bonomo, M.; Naponiello, G.; Venditti, I.; Zardetto, V.; Di Carlo, A.; Dini, D. Electrochemical and Photoelectrochemical Properties of Screen-Printed Nickel Oxide Thin Films Obtained from Precursor Pastes with Different Compositions. J. Electrochem. Soc. 2016, 164, H137-H147. [CrossRef]

13. Di Girolamo, D.; Matteocci, F.; Piccinni, M.; Di Carlo, A.; Dini, D. Anodically electrodeposited NiO nanoflakes as hole selective contact in efficient air processed p-i-n perovskite solar cells. Sol. Energy Mater. Sol. Cells 2020, 205, 110288. [CrossRef]

14. Di Girolamo, D.; Di Giacomo, F.; Matteocci, F.; Marrani, A.G.; Dini, D.; Abate, A. Progress, highlights and perspectives on NiO in perovskite photovoltaics. Chem. Sci. 2020, 11, 7746-7759. [CrossRef]

15. Bonomo, M.; Dini, D.; Decker, F. Electrochemical and Photoelectrochemical Properties of Nickel Oxide (NiO) With Nanostructured Morphology for Photoconversion Applications. Front. Chem. 2018, 6, 601. [CrossRef] [PubMed]

16. Bonomo, M.; Sheehan, S.; Dowling, D.P.; Gontrani, L.; Dini, D. First Evidence of Electrode Reconstruction in Mesoporous NiO After Operation as Photocathode of Dye-Sensitized Solar Cells. ChemistrySelect 2018, 3, 6729-6736. [CrossRef]

17. Sahu, D.; Lee, Y.-H.; Wu, T.-J.; Wang, S.-C.; Huang, J.-L. Synthesis and electrochromic property improvement of NiO films for device applications. Thin Solid Films 2020, 707, 138097. [CrossRef]

18. Sarkar, K.; Debnath, A.; Deb, K.; Bera, A.; Saha, B. Effect of NiO incorporation in charge transport of polyaniline: Improved polymer based thermoelectric generator. Energy 2019, 177, 203-210. [CrossRef]

19. Nakate, U.T.; Ahmad, R.; Patil, P.; Yu, Y.; Hahn, Y.-B. Ultra thin NiO nanosheets for high performance hydrogen gas sensor device. Appl. Surf. Sci. 2020, 506, 144971. [CrossRef]

20. Gagaoudakis, E.; Michail, G.; Kampylafka, V.; Tsagaraki, K.; Aperathitis, E.; Moschovis, K.; Binas, V.; Kiriakidis, G. Room Temperature p-Type NiO Nanostructure Thin Film Sensor for Hydrogen and Methane Detection. Sens. Lett. 2017, 15, 663-667. [CrossRef]

21. Zhang, S.; Li, Y.; Sun, G.; Zhang, B.; Wang, Y.; Cao, J.; Zhang, Z. Enhanced methane sensing properties of porous NiO nanaosheets by decorating with $\mathrm{SnO}_{2}$. Sens. Actuators B Chem. 2019, 288, 373-382. [CrossRef]

22. Urso, M.; Leonardi, S.G.; Neri, G.; Petralia, S.; Conoci, S.; Priolo, F.; Mirabella, S. Room temperature detection and modelling of sub-ppm $\mathrm{NO}_{2}$ by low-cost nanoporous $\mathrm{NiO}$ film. Sens. Actuators B Chem. 2020, 305, 127481. [CrossRef]

23. Su, C.; Zhang, L.; Han, Y.; Ren, C.; Chen, X.; Hu, J.; Zeng, M.; Hu, N.; Su, Y.; Zhou, Z.; et al. Controllable synthesis of crescent-shaped porous $\mathrm{NiO}$ nanoplates for conductometric ethanol gas sensors. Sens. Actuators B Chem. 2019, 296, 126642. [CrossRef]

24. Demin, V.S.; Krasovskii, A.N.; Lyudchik, A.M.; Pokatashkin, V.I.; Grigorishin, I.L.; Kudanovich, O.N. Measurement of ozone over a wide range of concentrations using semiconductor $\mathrm{NiO}$ gas sensors. Meas. Tech. 2008, 51, 1038-1044. [CrossRef]

25. Nandy, S.; Maiti, U.N.; Ghosh, C.K.; Chattopadhyay, K.K. Enhanced p-type conductivity and band gap narrowing in heavily Al doped $\mathrm{NiO}$ thin films deposited by RF magnetron sputtering. J. Phys. Condens. Matter 2009, 21, 115804. [CrossRef]

26. Wang, S.; Huang, D.; Xu, S.; Jiang, W.; Wang, T.; Hu, J.; Hu, N.; Su, Y.; Zhang, Y.; Yang, Z. Two-dimensional NiO nanosheets with enhanced room temperature $\mathrm{NO}_{2}$ sensing performance via Al doping. Phys. Chem. Chem. Phys. 2017, 19, 19043-19049. [CrossRef] [PubMed]

27. Kampitakis, V.; Gagaoudakis, E.; Zappa, D.; Comini, E.; Aperathitis, E.; Kostopoulos, A.; Kiriakidis, G.; Binas, V. Highly sensitive and selective $\mathrm{NO}_{2}$ chemical sensors based on $\mathrm{Al}$ doped $\mathrm{NiO}$ thin films. Mater. Sci. Semicond. Process. 2020, 115, 105149. [CrossRef]

28. Wang, C.; Cui, X.; Liu, J.; Zhou, X.; Cheng, X.; Sun, P.; Hu, X.; Li, X.; Zheng, J.; Lu, G. Design of Superior Ethanol Gas Sensor Based on Al-Doped NiO Nanorod-Flowers. ACS Sens. 2016, 1, 131-136. [CrossRef]

29. Abdul-Hussein, Y.M.; Ali, H.J.; Latif, L.A.; Abdulsattar, M.A.; Fadhel, H.M. Preparation of Al-Doped NiO Thin Films by Spray Pyrolysis Technique for CO Gas Sensing. J. Adv. Pharm. Educ. Res. 2019, 9, 1-6.

30. Gagaoudakis, E.; Michail, G.; Katerinopoulou, D.; Moschovis, K.; Iliopoulos, E.; Kiriakidis, G.; Binas, V.; Aperathitis, E. Transparent p-type NiO:Al thin films as room temperature hydrogen and methane gas sensors. Mater. Sci. Semicond. Process. 2020, 109, 104922. [CrossRef]

31. Siddique, M.N.; Ahmed, A.; Tripathi, P. Electric transport and enhanced dielectric permittivity in pure and Al doped NiO nanostructures. J. Alloys Compd. 2018, 735, 516-529. [CrossRef]

32. Liu, L.; Li, T.; Yi, Z.; Chi, F.; Lin, Z.; Zhang, X.; Xu, K. Conductometric ozone sensor based on mesoporous ultrafine Co3O4 nanobricks. Sens. Actuators B Chem. 2019, 297, 126815. [CrossRef]

33. Mokoena, T.P.; Swart, H.C.; Motaung, D.E. A review on recent progress of p-type nickel oxide based gas sensors: Future perspectives. J. Alloys Compd. 2019, 805, 267-294. [CrossRef]

34. Sun, Q.; Wu, Z.; Cao, Y.; Guo, J.; Long, M.; Duan, H.; Jia, D. Chemiresistive sensor arrays based on noncovalently functionalized multi-walled carbon nanotubes for ozone detection. Sens. Actuators B Chem. 2019, 297, 126689. [CrossRef]

35. Onofre, Y.J.; Catto, A.C.; Bernardini, S.; Fiorido, T.; Aguir, K.; Longo, E.; Mastelaro, V.R.; da Silva, L.F.; de Godoy, M.P. Highly selective ozone gas sensor based on nanocrystalline $\mathrm{Zn}_{0.95} \mathrm{Co}_{0.05} \mathrm{O}$ thin film obtained via spray pyrolysis technique. Appl. Surf. Sci. 2019, 478, 347-354. [CrossRef]

36. Wu, C.-H.; Jiang, G.-J.; Chang, K.-W.; Deng, Z.-Y.; Li, Y.-N.; Chen, K.-L.; Jeng, C.-C. Analysis of the Sensing Properties of a Highly Stable and Reproducible Ozone Gas Sensor Based on Amorphous In-Ga-Zn-O Thin Film. Sensors 2018, 18, 163. [CrossRef] [PubMed]

37. Catto, A.C.; Da Silva, L.F.; Ribeiro, C.; Bernardini, S.; Aguir, K.; Longo, E.; Mastelaro, V.R. An easy method of preparing ozone gas sensors based on ZnO nanorods. RSC Adv. 2015, 5, 19528-19533. [CrossRef]

38. Joshi, N.; Da Silva, L.F.; Jadhav, H.; M'Peko, J.-C.; Torres, B.B.M.; Aguir, K.; Mastelaro, V.R.; Oliveira, O.N. One-step approach for preparing ozone gas sensors based on hierarchical $\mathrm{NiCo}_{2} \mathrm{O}_{4}$ structures. RSC Adv. 2016, 6, 92655-92662. [CrossRef] 